\title{
The Effect of Sedentary Lifestyle on the Incidence of Obesity on Adolescents in SMUN 7 Banda Aceh
}

\author{
Yuliana Asnita ${ }^{1}$, Evawany Yunita Aritonang 2 , Zulhaida Lubis ${ }^{3}$ \\ ${ }^{1}$ Postgraduate Study Program of Public Health, Faculty of Public Health, University of North Sumatra, \\ Indonesia \\ ${ }^{2}$ Department of Epidemiology, Faculty of Public Health, University of North Sumatra, Indonesia \\ ${ }^{3}$ Department of Health Nutrition, Faculty of Public Health, University of North Sumatra, Indonesia \\ Email: Ananda.nita@yahoo.com
}

\begin{abstract}
:
The number of obesity populations worldwide has risen sharply in the last decade. Obesity does not only occur in adulthood but can also be experienced in childhood and adolescence. Many factors cause obesity, minimal physical activity is one of the factors causing obesity in adolescents. This type of research is an observational analytic study with a case-control design. The population of the study was all students of class X and XI at SMUN 7 Banda Aceh. The sample was divided into two groups: cases with students who had obesity nutritional status and a control group with students who had normal nutritional status. The sample size for the case were 50 students and cases of 100 students, the total sample were 150 students. Sampling was done by systematic random sampling technique. The research data were analyzed using univariate analysis and bivariate analysis. The results showed that variables related to obesity were watching TV $(p=$ $0.021, O R=2.48, C I=1,208-5,126)$, using gadgets $(p=0,023, O R=3,83, C I=1,254-11,719)$, doing tasks with internet $(p=0,000$ OR $=5,16 C I=2,483-10,749)$ doing tasks without internet ( $p$ $=0.002 \mathrm{OR}=3.25 \mathrm{CI}=1,588-6,650)$ following less and recite $(p=0.003 \mathrm{OR}=3.143 \mathrm{CI}=1,511$ $6,537)$ get together with friends $(p=0.002$ OR $=3,273 C I=1,611-6,697)$.

Keywords:

sedentary lifestyle; obesity; adolescents
\end{abstract}

\section{Introduction}

The prevalence of obesity throughout the world has risen sharply in the last decade, so it has become a nutritional problem that needs serious attention (Sudargo, 2018). Based on data from the World Health Organization (WHO, 2017), the prevalence of fat and obesity in the group of childhood and adolescents aged 5-19 years has increased significantly from four percent in 1975 to more than 18 percent in 2016.

Nutritionally vulnerable phase can be experienced in adolescence for various reasons. First, adolescents will experience significant growth, physical growth and development so they need higher nutrients. Second, the intake or nutritional needs are influenced by changes in lifestyle and eating habits of adolescents and lack of physical activity so that it leads to sedentary lifestyles (Almatsier et al, 2011).

Most teenagers now have decreased physical activity each year. Low physical activity carried out by adolescents will lead to an increase in sedentary lifestyle, where adolescents will spend a lot of time in front of the screen activities (watching TV, playing games, and using computer), reading, sitting and relaxing. Sedentary comes from the Latin sedere which means sitting, consisting of sitting during leisure time, traveling, and at work and household. 
Examples of sedentary behavior are watching television (TV), playing video games, using computers, reading, talking on the phone, and sitting while traveling by car, bus, boat, train, plane, and others. These activities show low energy expenditure (Leitzmann et al., 2017).

The development of technology and everything that is instantaneous as it is today makes people's lifestyle changes. In urban areas, office buildings to modern shopping centers use comfortable elevators or escalators without sweat to use them. Not to mention the development of high-tech television that spoil users, from high definition (HD) technology to three dimensions, making television viewers reluctant to move from in front of these sophisticated screens.

In fact, television currently provides surfing facilities on the internet known as smart television. Technology that makes it easy for humans to tend to be lazy to move (Ariadna, 2016). The behavior of someone who shows less physical activity and more activities that do not require a lot of energy which is a term of a sedentary lifestyle (Gentile, 2011). Katzmarzyk and Lee, (2012) conducted an American study of sedentary behavior with the cut-off points used that is $<3$ hours, 3-5 hours and $\geq 6$ hours, showing that sedentary activities carried out to reduce up to $<3$ hours per day can increase life expectancy by 2 years.

America Academy of Pediatrics (AAP, 2001), recommends that parents limit the total time of children's entertainment media to no more than 2 hours per day. Biddle (2010) states, this recommendation is very important because sedentary behavior can carry health risks for children and adolescents.

Based on this background, the authors conducted a preliminary survey that conducted at SMUN 7. The school is one of the superior senior high schools in Banda Aceh which is located in a very strategic place. The average student at the school is facilitated by public and private vehicles which then reduce their frequency in walking. Coupled with the availability of electronic devices such as personal cellphones, laptops, and televisions that cause their physical activity to be increasingly minimal.

The specific purpose of this study was to determine the effect of a sedentary lifestyle which includes the type of sedentary activity and the level of sedentary activity on the incidence of obesity in adolescents at SMUN 7 Banda Aceh.

\section{Research Methods}

This type of research is an observational analytic study with a case-control design. The population in this study were all students of class X and class XI at SMUN 7 Banda Aceh as many as 150 people, the case population was all students who were obese and the control population was all students with normal nutritional status. The sample size used in the case control study was calculated using the Lemeshow sample formula in Nugrahaeni, (2011), as below:

$$
\mathrm{n}=\frac{\left\{\mathrm{Z}_{1-\propto / 2} \sqrt{[2 \mathrm{P}(1-\mathrm{P})]}+\mathrm{Z}_{1-\beta} \sqrt{\left[\mathrm{P}_{1}\left(1-\mathrm{P}_{1}\right)+\mathrm{P}_{2}\left(1-\mathrm{P}_{2}\right)\right]}\right\}^{2}}{\left(\mathrm{P}_{1}-\mathrm{P}_{2}\right)^{2}}
$$


Information :

$\mathrm{n} \quad=$ Sample size

$\mathrm{P}_{1} \quad=$ The proportion of obesity in the case group (0,62) (Irdianty, et al 2016)

$\mathrm{P}_{2}=$ The proportion of non-obese in the control group $(0,43)$

$Z_{1-\alpha / 2}=Z$ value in the degree of trust $1-\alpha Z=1,96$ for the degree of trust $95 \%$

$Z_{1-\beta}=Z$ value on test strength $1-\beta 20 \%=0,842$

From the sample calculation, 43 people were rounded up to 50 people. The total sample were 150 people (consisting of 50 cases and 100 people as controls). The steps in determining the sample are cases taken from students who meet the criteria of the case that is identified obesity in the research stage of nutritional status screening, cases are randomly selected using simple random techniques, all obese students are written down on a small piece of paper, then rolled up, all rolls of paper are shaken, then drawn one by one as members of the sample as many samples as needed (Sumantri, 2015).

Control was taken from students without obesity with normal nutritional status from the same school as the case. Controls were randomly selected from all students belonging to the nonobese (normal) group using a systematic random sampling technique (Systematic random sampling). Data collection for sedentary activities was carried out by direct interview using the Adolescent Sedentary Activity Questionnaire (ASAQ) questionnaire by identifying 11 sedentary behaviors from Monday to Sunday (Hardy, 2007). Data analysis techniques were carried out univariate and bivariate.

\section{Discussion}

\subsection{Univariate}

Table 1. Distribution of Respondents based on Characteristics at SMAN 7 Banda Aceh

\begin{tabular}{lll}
\hline \multirow{2}{*}{ Characteristics } & Total & \\
\cline { 2 - 3 } & $\mathbf{n}=\mathbf{1 5 0}$ & $\mathbf{0}$ \\
\hline Gender & & \\
$\quad$ Male & 61 & 40.7 \\
$\quad$ Female & 89 & 59.3 \\
Parents' job & & \\
$\quad$ Does not work & 74 & 49.3 \\
$\quad$ Work & 76 & 50.7 \\
Parent's income & & \\
$\quad>5.000 .000 /$ month & 135 & 90 \\
$\quad \leq 5.000 .000 /$ month & 15 & 10 \\
Pocket money & & \\
$\quad>15.000 /$ day & 108 & 72 \\
$\quad \leq 15.000 /$ day & 42 & 28 \\
\hline
\end{tabular}

In the table above, it can be seen that there are more female respondents than male respondents. There are also more respondents that have mother who work than those who do not work. Mothers who work will spend a lot of time to work, so mothers do not have enough time to give attention in terms of physical activity. 
As a result, children will prefer to relax by lying down and using gadgets that lead to minimal activity. This table also shows that the average income of parents of teenagers at SMUN 7 Banda Aceh is $>$ Rp. 5,000,000 / month, with a high enough income parents have the ability to provide transportation facilities to school for their children. Judging from the allowance every day, the average teenager has pocket money> Rp. 15,000, pocket money is money given by parents to meet the needs of adolescents during school so that with enough allowance they can buy the snacks they want.

\subsection{Bivariate}

Table 2. Distribution of Sedentary Activity Types with Obesity Incident in Adolescents at SMUN 7 Banda Aceh

\begin{tabular}{|c|c|c|c|c|c|c|c|}
\hline \multirow{2}{*}{ Sedentary Activity } & \multicolumn{2}{|c|}{ Obesity } & \multicolumn{2}{|c|}{ Normal } & \multirow{2}{*}{$\mathbf{O R}$} & \multirow{2}{*}{$95 \% \mathrm{CI}$} & \multirow{2}{*}{$\boldsymbol{P}$} \\
\hline & $n=50$ & $\%$ & $\mathrm{n}=100$ & $\%$ & & & \\
\hline \multicolumn{8}{|l|}{ Watching TV } \\
\hline$>2$ Hours/Day & 22 & 47,8 & 24 & 52,2 & \multirow{2}{*}{2,48} & $1,208-$ & \multirow{2}{*}{0,021} \\
\hline$\leq 2$ Hours/Day & 28 & 26,9 & 76 & 73,1 & & 5,126 & \\
\hline \multicolumn{8}{|l|}{ Watching DVD/Video } \\
\hline$>2$ Hours/Day & 9 & 42,9 & 12 & 57,1 & \multirow{2}{*}{1,61} & $0,629-$ & \multirow{2}{*}{0,454} \\
\hline$\leq 2$ Hours/Day & 41 & 31,8 & 88 & 68,2 & & 4,122 & \\
\hline \multicolumn{8}{|l|}{ Using Gadget } \\
\hline$>2$ Hours/Day & 46 & 38 & 75 & 62,0 & \multirow{2}{*}{3,83} & $1,254-$ & \multirow{2}{*}{0,023} \\
\hline$\leq 2$ Hours/Day & 4 & 13,8 & 25 & 86,2 & & 11,719 & \\
\hline \multicolumn{8}{|c|}{$\begin{array}{l}\text { Doing tasks with the Internet } \\
\text { or Computer }\end{array}$} \\
\hline$>2$ Hours/Day & 31 & 56,4 & 24 & 43,6 & \multirow{2}{*}{5,16} & $2,483-$ & \multirow{2}{*}{0,000} \\
\hline$\leq 2$ Hours/Day & 19 & 20 & 76 & 80 & & 10,749 & \\
\hline \multicolumn{8}{|c|}{ Doing tasks without internet } \\
\hline$>2$ Hours/Day & 26 & 51 & 25 & 49,0 & \multirow{2}{*}{3,25} & $1,588-$ & \multirow{2}{*}{0,002} \\
\hline$\leq 2$ Hours/Day & 24 & 24,2 & 75 & 75,8 & & 6,650 & \\
\hline \multicolumn{8}{|c|}{ Reading comic or Magazine } \\
\hline$>2$ Hours/Day & 7 & 50 & 7 & 50,0 & \multirow{2}{*}{2,163} & $0,714-$ & \multirow{2}{*}{0,275} \\
\hline$\leq 2$ Hours/Day & 43 & 31,6 & 93 & 68,0 & & 6,551 & \\
\hline \multicolumn{8}{|c|}{$\begin{array}{l}\text { Following private school or } \\
\text { learn Al-quran }\end{array}$} \\
\hline$>2$ Hours/Day & 36 & 44,4 & 45 & 55,6 & \multirow{2}{*}{3,143} & $1,511-$ & \multirow{2}{*}{0,003} \\
\hline$\leq 2$ Hours/Day & 14 & 20,3 & 55 & 79,7 & & 6,537 & \\
\hline \multicolumn{8}{|c|}{$\begin{array}{l}\text { Using transportation } \\
\text { school }\end{array}$} \\
\hline$>2$ Hours/Day & 10 & 52,6 & 9 & 47,4 & \multirow{2}{*}{2,52} & $0,954-$ & 0009 \\
\hline$\leq 2$ Hours/Day & 40 & 40,5 & 91 & 69,5 & & 6,697 & 0,099 \\
\hline Doing hobby or craft & & & & & & & \\
\hline$>2$ Hours/Day & 19 & 54,3 & 16 & 45,7 & & 0,249 & \\
\hline$\leq 2$ Hours/Day & 31 & 27 & 84 & 73 & 3,218 & 2,2217 & 0,790 \\
\hline Gather with friends & & & & & & & \\
\hline$>2$ Hours/Day & 28 & 50 & 28 & 50,0 & & $1,611-$ & \\
\hline$\leq 2$ Hours/Day & 22 & 23,0 & 72 & 76,6 & $3,2 / 3$ & 6,649 & 0,002 \\
\hline
\end{tabular}

Playing the music 


$\begin{array}{llllllll}>2 \text { Hours/Day } & 10 & 45,5 & 12 & 54,5 & 1,83 & 0,732- & 0,289 \\ \leq 2 \text { Hours/Day } & 40 & 31,3 & 88 & 68,8 & & 4,594 & \end{array}$

The results of the distribution of the types of sedentary activities in the table above show that the majority of obese adolescents perform high sedentary activities $>2$ hours / day and vice versa adolescents with normal nutritional status mostly do low sedentary activities $<2$ hours / day. Sedentary activities that are often carried out by obese adolescents are watching TV, using a smartphone, gathering with friends, taking private lessons and studying, doing tasks without a computer or the internet, and doing tasks with the internet or computers. While the sedentary behavior that they rarely do is play music, read, and watch DVDs.

Previous research conducted by Putra (2017) on private high school adolescents in Surabaya, showed that of 181 students studied, classified as overweight as many as 141 students (77.9 percent). The results of an initial survey conducted by researchers showed that most children currently spend their time doing activities that plunge on sedentary activities such as watching TV, reading at leisure, playing games, and playing in front of a computer or laptop. The results of his research show that children who watch television or use computers $>4$ hours a day have a 2.5 times greater chance of being obese than children who watch TV or use computers for $\leq 1$ hour.

The Vilchis study (2015) also states that obese children spend less time on physical activity, they spend more time watching TV. Another study conducted by Kudraningsih (2017) explains that adolescents who go to school on foot or on bicycles have no risk of being obese compared to adolescents who use means of transportation such as motorbikes. Sedentary behavior is behavior that is characterized by little or no physical movement and low energy expenditure of less than 1.5 MET (Metabolic Equivalent Task).

The purpose of the MET is to assess energy expenditure during activities. Walking fast has a value of 3-4 MET and running can expend energy worth 8 MET, while sedentary behavior only emits less than 1.5 MET (Zhu \& Owen, 2017). Some individuals can be classified as sedentary based on their involvement in activities that do not require high energy input (Tremblay et al. 2011).

Table 3. Distribution of Sedentary Activity Levels to Obesity in Adolescents at SMUN 7 Banda Aceh

\begin{tabular}{|c|c|c|c|c|c|c|c|}
\hline \multirow{2}{*}{$\begin{array}{l}\text { Level of } \\
\text { Sedentary } \\
\text { Activity }\end{array}$} & \multicolumn{2}{|c|}{ Obesity } & \multicolumn{2}{|c|}{ Normal } & \multirow{2}{*}{ OR } & \multirow{2}{*}{$95 \% \mathrm{CI}$} & \multirow{2}{*}{$P$} \\
\hline & $\mathbf{n}$ & $\%$ & $\mathbf{n}$ & $\%$ & & & \\
\hline Hight & 39 & 78 & 58 & 58 & \multirow{3}{*}{2,567} & \multirow{3}{*}{$1,179-5,590$} & \multirow{3}{*}{0,025} \\
\hline Low & 11 & 22 & 42 & 42 & & & \\
\hline Total & 50 & 100 & 100 & 100 & & & \\
\hline
\end{tabular}

From the results of the table above it can be seen that the level of sedentari activity is high experienced by adolescents with obesity. Whereas adolescents with normal nutritional status tend to engage in low sedentary activities. This statement is in accordance with research conducted by Kumala, et al (2019) which states that as many as $77.8 \%$ of respondents in the obese category have low physical activity, and there is a significant relationship between the duration of use of transient activity with nutritional status in adolescents aged 13-15 year. 
A different matter was expressed by Ubaidillah (2019) who conducted a study at Semen Kediri SMPN 1, which stated that there was no significant relationship between sedentary activity and nutritional status, with a value of $0.68(>0.05)$ and acquisition of $-0,51 \%$, which means high temporary activity but normal nutritional status. The results of research conducted by Pramudhita and Nadhiroh (2018), stated that adolescents who perform high sedentary activities $>8$ hours / day totaling 31 people $(88.6 \%)$, most adolescents experience more nutritional status and only 4 people $(11.4 \%)$ who carry out sedentary activities $\leq 8$ hours / day. As many as 34 adolescents with normal nutrition have a low sedentary activity level jam8 hours / day (97.1\%) while those who do high sedentary activities $>8$ hours / day are only $2.9 \%$. High sedentary level $>8$ hours / day On average experienced by adolescents with more nutritional status.

\section{Conclusion}

Based on the results of analysis and discussion of the data, the authors can draw conclusions from research on the effect of sedentary lifestyles on the incidence of Obesity in Adolescents at SMUN 7 Banda Aceh, namely obese adolescents at SMUN 7 Banda Aceh carrying out high sedentary activities with an average value of $>2$ hours / day. Sedentary activities related to obesity are watching TV ( $\mathrm{p}=0.021, \mathrm{OR}=2.48, \mathrm{CI}=1,208-5,126)$, using gadgets $(\mathrm{p}=0,023$, $\mathrm{OR}=3,83$, CI $=1,254$ - 11,719), doing tasks with internet $(\mathrm{p}=0,000 \mathrm{OR}=5,16 \mathrm{CI}=2,483$ $10,749)$ doing tasks without internet $(\mathrm{p}=0.002 \mathrm{OR}=3.25 \mathrm{CI}=1,588-6,650)$ following less and recite $(\mathrm{p}=0.003 \mathrm{OR}=3.143 \mathrm{CI}=1,511-6,537)$ get together with friends $(\mathrm{p}=0.002 \mathrm{OR}=3,273$ $\mathrm{CI}=1,611-6,697)$.

Based on the results of research, discussion, and conclusions in this study, the researchers propose suggestions as follows the need for teacher collaboration to regularly monitor the nutritional status of adolescents, provide counseling or training to teachers about sedentary lifestyle risks. The need for cooperation between the government, health centers and schools in providing regular counseling in assessing the nutritional status of adolescents and the management of healthy canteens and involving parents in controlling to reduce the incidence of obesity in adolescents. 


\section{References}

Arundhana, A. I. (2013). Pola perilaku sedentari merupakan faktor resiko kejadian obesitas pada anak sekolah dasar di Kota Yogyakarta Dan Kabupaten Bantul (Doctoral dissertation, Universitas Gadjah Mada).

Almatsier, \& Sunita. (2011). Prinsip dasar ilmu gizi. Jakarta: Gramedia pustaka utama.

Ariadna,I. (2016). Bahaya obesitas dalam hidup sedentari. Diakses di: https://www.indriariadna.com/2016/06/bahaya-obesitas-dalam-gaya-hidup.html

Biddle, S., Cavill, N., Ekelund, U., Gorely, T., Griffiths, M., Jago, R., \& Vicente-Rodríguez, G. (2010). Sedentary behaviour and obesity: review of the current scientific evidence.

Hardy, L. L., Booth, M. L., \& Okely, A. D. (2007). The reliability of the adolescent sedentary activity questionnaire (ASAQ). Preventive medicine, 45(1), 71-74.

Irdianty, M. S., Sudargo, T., \& Hakimi, M. (2016). Aktivitas fisik dan konsumsi camilan pada remaja obesitas di pedesaan dan perkotaan Kabupaten Bantul. Berita Kedokteran Masyarakat, 32(7), 217-222.

Katzmarzyk, P. T., \& Lee, I. M. (2012). Sedentary behaviour and life expectancy in the USA: a cause-deleted life table analysis. BMJ open, 2(4), e000828.

Kurdaningsih, S. V., Sudargo, T., \& Lusmilasari, L. (2017). Physical activity and sedentary lifestyle towards teenagers' overweight/obesity status. International Journal of Community Medicine and Public Health, 3(3), 630-635.

Kumala, A. M., Margawati, A., \& Rahadiyanti, A. (2019). Hubungan antara durasi penggunaan alat elektronik (gadget), aktivitas fisik dan pola makan dengan status gizi pada remaja usia 13-15 tahun. Journal of Nutrition College, 8(2), 73-80.

Leitzmann, M. F., Jochem, C., and Schmid, D. (2017). Sedentary behaviour epidemiology. Germany. Springer

Putra, W. N. (2017). The Association between dietary pattern, physical activity, sedentary activity and overweight at SMA Negeri 5 Surabaya. Jurnal Berkala Epidemiologi, 5(3), 298-310.

Pramudita, S. R., \& Nadhiroh, S. R. (2018).Gambaran aktivitas sedentari dan tingkat kecukupan gizi pada remaja gizi lebih dan gizi normal. Media Gizi Indonesia, 12(1), 1-6.

Pramita, R. D., \& Griadhi, I. P. A. (2015). Hubungan antara perilaku sedentari dengan indeks massa tubuh pada siswa kelas V di SD Cipta Dharma Denpasar. Denpasar: Universitas Udayana, Fakultas Kedokteran.

Sudargo, T., Freitag, H., Kusmayanti, N.A., \& Rosiyani, F. (2018). Pola makan dan obesitas. Yogjakarta: UGM Press.

Tremblay, M. S., LeBlanc, A. G., Kho, M. E., Saunders, T. J., Larouche, R., Colley, R. C., \& Gorber, S. C. (2011). Systematic review of sedentary behaviour and health indicators in school-aged children and youth. International journal of behavioral nutrition and physical activity, 8(1), 98.

Ulilalbab, A., Anggaini, E., \& Lestari, I. A. (2017). Obesitas anak usia sekolah. Yogjakarta. Deepublish

Ubaidilah, M. (2019). Hubungan Antara Aktivitas Sedentari Dengan Status Gizi Pada Peserta Didik Kelas VII SMPN 1 Semen Kabupaten Kediri. Jurnal Pendidikan Olahraga dan Kesehatan, 7(3). 
Vilchis-Gil, J., Galván-Portillo, M., Klünder-Klünder, M., Cruz, M., \& Flores-Huerta, S. (2015). Food habits, physical activities and sedentary lifestyles of eutrophic and obese school children: a case-control study. BMC public health, 15(1), 124.

WHO. (2018). Obesity and Overweight. Diakses di http://www.who.int.

Zhu, W., Owen, N. (2017). Sedentary behavior and health: concepts, assessments, and interventions. United States of America. Human Kinetics 